\title{
HARGA DIRI DAN KONFORMITAS TERHADAP KELOM POK DENGAN PERILAKU MINUM MINUMAN BERALKOHOL PADA REMAJA
}

\author{
Cipto \& Joko Kuncoro \\ Fakultas Psikologi Universitas Islam Sultan Agung
}

\begin{abstract}
The major purpose of this research is to find the relations between self esteem and conformity with dringking behavior. This study also try to find the contribution of each independen variabel to the dependen variabel. The sample of this research are 52 teenages who watch rock music concert at kudus.

The result of this study using multiple regression technique show that there was significan correlation between between self esteem and conformity with dringking behavior with $R=0,125 ; p=0,000$ ( $p<0,01$; significan), $F=21,386$ dan $p=0,000$. Statistical analysis also shows that there was positive significan correlation between self esteem and drinkin behavior with $r_{x y}=-0,313 ; p=0,000(p<0,01)$. The relation between conformity and drinking behavior is positive significa with $r_{x y}=0,397$; $p=0,000(p<0,01)$. This is mean tha all hypothesis are proven or accepted.

The final conclusion of this study is there is significan relationship between self esteem and conformity with drinking behavior among teenage at kudus.
\end{abstract}

Keyword : drinking behavior, self esteem, conformity

\section{Pendahuluan}

Istilah "alkohol" sebenarnya ditujukan pada sekelompok besar molekul organik yang memiliki gugus hidroksil $(-\mathrm{OH})$ yang melekat pada atom jenuh. Etil alkohol juga disebut juga dengan etanol, adalah bentuk alkohol yang umum seringkali disebut dengan alkohol minuman. Senyawa termasuk metanol, butanol aldehida, fenol, tannis dan sejumlah kecil berbagai logam terkandung dalam minuman beralkohol yang menyebabkan efek psikoaktif (Kaplan dan Sandock, 1997, h.596).

Minuman beralkohol selain merusak kesehatan secara fisik, dapat menimbulkan gangguan kepribadian seperti mudah tersinggung dan perhatian 
terhadap lingkungan menjadi terganggu sehingga sering menunjukkan kecenderungan marah dan sikap agresi. Kadar alkohol dalam taraf atau BAC (blood alcohol concentration) 0,01 persen akan menyebabkan gangguan pada fungsi motorik dan sensorik sehingga bicara mengalami kesulitan koordinasi serta akan cenderung melakukan agresi, karena keagresifan serta tertekannya pengendalian diri tersebut seseorang cenderung melakukan gangguan keamanan dan ketertiban masyarakat baik dalam bentuk pelanggaran norma-norma atau sikap moral bahkan melakukan tindakan pidana atau kriminal.

Gangguan penggunaan obat zat psikoaktif (narkotika, alkohol maupun zat adiktif lainnya) dalam taraf ketergantungan merupakan manifestasi gangguan jiwa, bentuk penyimpangan perilaku dari norma-norma yang umumnya berlaku pada berbagai kebudayaan di dunia. Sebagian besar dari orang yang mengalami gangguan penggunaan zat tergolong remaja dan dewasa muda, seperti yang telah dilaporkan oleh Husin (Siregar, 2000, h.24) bahwa dari pasien yang datang berobat ke rumah sakit ketergantungan obat dan alkohol sebagian adalah laki-laki (94 persen) dan dalam golongan usia 16-25 tahun atau remaja (71 persen).

Monks (1998, h.260) menyatakan bahwa masa remaja menunjukkan sifatsifat masa transisi atau peralihan karena remaja belum memperoleh status orang dewasa tetapi tidak lagi memiliki status anak-anak. Masa remaja sering disebut juga adolescence yang artinya menjadi dewasa atau dalam perkembangan menjadi dewasa. M onks (1998, h.262) menetapkan batasan usia remaja antara 12-21 tahun yang dibagi dalam tiga fase, yaitu 12-15 tahun sebagai remaja awal, 15-18 tahun sebagai remaja pertengahan dan 18-21 sebagai remaja akhir. Remaja berkembang ke arah kematangan seksual serta memantapkan identitas dirinya, periode ini merupakan masa yang kritis bagi individu dalam memantapkan pengalaman yang diperoleh sejak kecil dalam membentuk kepribadian. Periode ini juga merupakan periode dimana seseorang cenderung menolak apa yang dikehendaki oleh lingkungan sekitarnya. Perilaku mereka yang cenderung menolak lingkungannya membuat remaja sering menimbulkan masalah-masalah di lingkungan sekitar. Salah satu masalah yang muncul adalah perilaku minum minuman beralkohol.

Perilaku minum minuman beralkohol dipengaruhi oleh kepribadian individu seperti adanya gangguan emosional, kurangnya rasa percaya diri dan harga diri yang rendah. Individu yang mempunyai harga diri tinggi biasanya menganggap dirinya berharga akan dapat mengendalikan diri untuk tidak berbuat hal-hal yang 
bertentangan dengan keadaan yang ideal dengan dirinya. Di lain pihak seseorang yang mempunyai harga diri rendah biasanya menganggap dirinya tidak berharga akan melakukan hal-hal negatif yang menurutnya dianggap ideal meskipun dianggap tidak ideal bagi lingkungan masyarakat untuk menutupi rasa tidak berharga dirinya. Dengan demikian jelaslah bahwa harga diri dianggap mempunyai peranan yang besar dalam kaitannya dengan pembentukan perilaku minum minuman beralkohol.

Individu yang dapat menghargai dirinya adalah individu yang memiliki harga diri yang positif. Merasa dirinya sebagai orang yang memiliki keterbatasan serta berusaha untuk mengembangkan dirinya, sedangkan individu yang memiliki harga diri yang rendah atau negatif biasanya akan merasa kurang puas, kurang mampu, kurang berharga, kurang berdaya dan rendah diri. Seseorang yang mempunyai harga diri rendah bisanya akan cenderung mengikatkan diri dengan kelompok sebayanya, hal tersebut dilakukan dengan tujuan supaya dirinya dianggap dan diakui di lingkungan kelompoknya.

http://community.gunadarma. ac.id/public/user/blogs/name_LeonardFresly92/page_2/).

Penelitian ini mengkhususkan pada remaja yang menonton konser musik rock, hal ini dikarenakan musik rock merupakan salah satu jenis musik yang dikenal sebagai musik yang memiliki irama dan lirik yang keras, hingar bingar, serta konser-konsernya sering diwarnai dengan kerusuhan.

Berdasarkan hasil pengamatan yang dilakukan oleh peneliti pada tanggal 24 Januari 2009 pukul 14.00-22.15 WIB pada acara konser musik rock "Embrace The Emotion From East To Shoutheast Friendship Journey" di Auditorium Universitas M uria Kudus, didapati sekelompok remaja yang sedang minum minuman beralkohol yang dilakukan diantara kerumunan penonton dan di belakang panggung. Acara ini dimeriahkan oleh band luar negeri seperti, Dying In Emotion, Full Jin, Tyran, Josephine dan band lokal seperti, Alicia and M emory, Unbroken, Atas Bawah, Immortal dan Feed Back.

Observasi kedua dilakukan pada tanggal 15 Pebruari 2009 pukul 09.00-15.40 WIB yang bertempat di gedung KNPI kompleks GOR Wergu Wetan Kudus dan bertema save my world. Acara ini dimeriahkan oleh band lokal seperti, hopeless, all teenage basrard, my luph fuckin' death, romantic in black dan zero parade. Peneliti mendapati hasil yang serupa dengan pengamatan yang pertama.

Remaja yang berperilaku minum minuman beralkohol, menjadi sebuah fenomena yang cukup menarik bagi peneliti, terlebih jika remaja tersebut melakukannya atas dasar untuk menyamakan diri dengan kelompok yang disukainya. 
Berdasarkan uraian di atas, menimbulkan pertanyaan bagi peneliti apakah ada hubungan antara harga diri dan konformitas terhadap kelompok dengan perilaku minum minuman beralkohol pada remaja?

Menurut Sears dkk (1994, hal. 138) perilaku merupakan kesiapan individu untuk bereaksi atau kecenderungan untuik bertindak terhadap objek. Perilaku yang ada pada individu tidak timbul dengan sendirinya melainkan sebagai akibat dari stimulus eksternal maupun internal (Walgito, 2001, hal. 15). Perilaku menurut Azwar (1995, h.34) adalah reaksi yang dapat bersifat sederhana maupun kompleks serta mempunyai sifat diferensial, artinya satu stimulus dapat menimbulkan lebih dari satu respon yang berbeda dan beberapa stimulus yang berbeda dapat saja menimbulkan satu respon yang sama.

Hawari (1991, h.4) menyebutkan bahwa minuman beralkohol dibagi menjadi tiga golongan, yaitu:

a. Golongan A (jenis bir, guiness dan lain-lain) yang berkadar alkohol 1 persen 5 persen

b. Golongan B (jenis congyang, anggur merah, anggur putih, newport dan lainlain) yang berkadar alkohol 5 persen - 20 persen

c. Golongan C (jenis mansion, vodka, red label, countreu, oplosan dan lain-lain) yang berkadar alkohol 20 persen - 50 persen

Yanny (2001, h.14) menyatakan bahwa alkohol dapat diperoleh dari hasil peragian atau fregmentasi oleh mikroorganisme (sel ragi) dari gula, sari buah, bijibijian, madu, umbi-umbian dan getah kaktuk tertentu. Proses peragian menghasilkan minuman dengan kadar alkohol hingga 14 persen sedangkan proses penyulingan akan mempertinggi kadar alkohol, bahkan hingga mencapai 100 persen.

Kebutuhan yang tidak terpuaskan pada diri remaja akan menyebabkan timbulnya perasaan frustrasi yang umumnya akan mengganggu berfungsinya kemampuan secara optimal. Remaja menjadi kurang dapat berpikir secara rasional dan kurang mampu mengarahkan masalah secara efektif, sehingga remaja akan terjerumus ke dalam perilaku negatif. Selain memiliki ciri khas di atas, remaja juga memiliki minatminat khusus, seperti minat rekreasi, minat sosial, minat pribadi, minat pada pendidikan, minat pada pekerjaan, minat pada agama dan minat pada simbol status (Hurlock, 1999, h.217).

Berdasarkan uraian beberapa teori mengenai perilaku, minuman beralkohol dan masa remaja maka dapat disimpulkan bahwa perilaku minum minuman beralkohol 
pada remaja adalah tindakan minum minuman beralkohol pada remaja yang berusia 12- 21 tahun yang terjadi karena adanya rangsangan atau stimulus baik dari dalam maupun dari luar individu yang dapat diamati atau dipelajari.

Aspek perilaku menurut Triford (Indraningtyas, 2003, h.16-17) dibagi menjadi tiga yaitu :

a. Frekuensi, yaitu sering tidaknya perilaku tersebut muncul. Frekuensi digunakan untuk mengetahui sejauhmana seseorang menyalahgunakan minuman beralkohol dengan menghitung jumlah munculnya perilaku tersebut.

b. Lamanya berlangsung, yaitu waktu yang diperlukan seseorang untuk melakukan setiap tindakan. Suatu perilaku mempunyai pemulaan dan akhir tertentu, tetapi dalam jangka waktu yang berbeda untuk masing-masing peristiwa, maka pengukuran dengan lamanya berlangsung akan lebih bermanfaat. Aspek lamanya berlangsung sangatlah berperan penting untuk menyatakan secara jelas dan terperinci perubahan dalam perilaku.

c. Intensitas, yaitu banyaknya daya yang dikeluarkan oleh perilaku tersebut. Aspek intensitas digunakan untuk mengukur seberapa dalam dan seberapa banyak seseorang meminum minuman beralkohol.

Karamoy $(2004$, h.2) menyebutkan bahwa ada dua faktor yang mempengaruhi perilaku minum minuman beralkohol yaitu faktor internal dan faktor eksternal.

1. Faktor Internal, antara lain : faktor kepribadian anak (termasuk didalamnya harga diri), pengaruh usia, pandangan atau keyakinan yang salah terhadap diri sendiri, religiusitas dan ego yang tidak realistis.

2. Faktor eksternal, antara lain : keluarga, lingkungan tempat tinggal, konformitas kelompok, keadaan sekolah dan pendidikan.

Berdasarkan uraian di atas dapat disimpulkan bahwa banyak faktor yang mempengaruhi perilaku minum minuman beralkohol, tetapi peneliti memilih faktor internal tentang kepribadian anak yaitu harga diri dan faktor eksternal yaitu konformitas kelompok sebagai variabel bebas dalam penelitian ini.

Clemes (1995, h.2) menyatakan bahwa harga diri adalah rasa nilai diri kita berasal dari seluruh pikiran, perasaan, sensasi dan pengalaman yang telah kita kumpulkan sepanjang hidup kita yang merupakan dasar bagi pertumbuhan positif dalam hubungan kemanusiaan, belajar kreativitas dan tanggung jawab pribadi. Santrock (1995, h.17) mengemukakan hal yang sama bahwa harga diri adalah perasaan tentang diri sendiri sehubungan dengan orang lain, berdasarkan rasa penerimaan diri. 
Aspek yang digunakan sebagai dasar pembuatan skala yaitu berdasarkan pendapat Noesjirwan (Putra, 2001, h.31), yang membagi aspek harga diri menjadi tiga yaitu:

a. Rasa diterima yaitu merasa sebagai bagian dari suatu kelompok, dihargai dan diterima oleh anggota kelompok.

b. Rasa dibutuhkan yaitu perasaan seseorang bahwa dirinya berharga dan bernilai.

c. Rasa mampu yaitu individu merasa mampu untuk melakukan sesuatu.

Myers (1991, h. 256) mengungkapkan bahwa konformitas adalah suatu perubahan sikap percaya sebagai akibat tekanan dari kelompok. Kiesler \& Kiesler (Rakhmat, 1991, h.150) menambahkan bahwa konformitas pada kelompok merupakan perilaku atau kepercayaan menuju norma kelompok sebagai akibat dari tekanan kelompok, baik nyata atau dibayangkan. Deaux (Zebua \& Nurdjayadi, 2001, h.75) juga menambahkan bahwa konformitas berarti tunduk pada kelompok meskipun tidak ada permintaan langsung untuk mengikuti apa yang telah diperbuat oleh kelompok.

Aspek yang digunakan sebagai dasar pembuatan skala konformitas yaitu berdasarkan pendapat Sears (1991, h.81-86) yang menyatakan bahwa aspek-aspek konformitas terhadap kelompok antara lain :
a. Kekompakan
b. Kesepakatan
c. Ketaatan

Berdasarkan teori tersebut di atas, maka hipotesis yang diajukan dan akan diuji kebenarannya dalam penelitian ini adalah :

1. Hipotesis Mayor yaitu : "Ada hubungan antara harga diri dan konformitas terhadap kelompok dengan perilaku minum minuman beralkohol pada remaja yang menonton konser musik rock."

2. Hipotesis M inor yaitu :

a. "Ada hubungan negatif antara harga diri dengan perilaku minum minuman beralkohol pada remaja yang menonton konser musik rock. Makin tinggi harga diri maka makin rendah perilaku minum minuman beralkohol pada remaja menonton konser musik rock, demikian sebaliknya."

b. "Ada hubungan positif antara konformitas terhadap kelompok dengan perilaku minum minuman beralkohol pada remaja yang menonton konser musik rock. Makin tinggi konformitas terhadap kelompok maka makin tinggi 
perilaku minum minuman beralkohol pada remaja menonton konser musik rock, demikian sebaliknya."

\section{Metode}

Penelitian ini menggunakan dua variabel bebas yaitu harga diri dan konformitas terhadap kelompok dan satu variabel tergantung yaitu perilaku minum minuman beralkohol. Populasi dan sampel pada penelitian ini adalah para remaja yang sedang menonton konser musik rock di Kota Kudus. Teknik pengambilan sampel yang dilakukan dalam penelitian ini menggunakan teknik incidental sampling, dimana pengambilannya berdasarkan pada subjek yang kebetulan ditemui dalam lokasi konser dan bersedia mengisi skala yang ditawarkan.

Metode pengumpulan data yang digunakan dalam penelitian ini adalah angket dan skala. Penelitian ini menggunakan satu macam angket yaitu angket perilaku minum minuman beralkohol dan dua macam skala yaitu skala harga diri dan skala konformitas terhadap kelompok.

Metode analisa data yang digunakan untuk menguji hipotesis pertama dengan menggunakan analisis regresi dan untuk menguji hipotesis kedua dan ketiga dengan menggunakan analisis korelasi parsial..

\section{Hasil}

Berdasarkan uji normalitas terhadap skala perilaku minum minuman beralkohol diperoleh koefisien $\mathrm{K}-\mathrm{SZ}=1,621$ dengan signifikansi $=0,210(p>0,05)$. Untuk skala harga diri memperoleh koefisien $\mathrm{K}-\mathrm{SZ}=0,648$ dengan signifikansi $=0,795$ $(p>0,05)$ dan skala konformitas terhadap kelompok memperoleh koefisien K-SZ =0,776 dengan signifikansi $=0,583(p>0,05)$. Hasil tersebut menunjukkan bahwa sebaran data ketiga variable penelitian adalah normal. Uji linearitas hubungan antara variabel harga diri dengan perilaku minum minuman beralkohol diperoleh Flin $=21,744 ; p=0,000$ ( $p<0,01$; signifikan). Hasil tersebut menunjukkan bahwa variabel harga diri dengan perilaku minum minuman beralkohol dalam penelitian ini korelasinya linear.

Uji linearitas hubungan antara variabel konformitas terhadap kelompok dengan perilaku minum minuman beralkohol diperoleh Flin $=25,294 ; p=0,000$ ( $p<0,01$; signifikan). Hasil tersebut menunjukkan bahwa variabel konformitas terhadap kelompok dengan perilaku minum minuman beralkohol dalam penelitian ini korelasinya linear. 
Uji Multikolinieritas dimaksudkan untuk mengetahui apakah antar variabel bebas terdapat hubungan atau tidak. Hasil pengujian diperoleh bahwa skor koefisien korelasi pada variabel bebas sebesar - 0,037 $(\varangle, 5)$ dengan skor VIF $=1,001(>1)$. Hal ini menunjukkan bahwa harga diri dan konformitas terhadap kelompok tidak terdapat masalah multikolinieritas.

Hasil analisis menunjukkan bahwa koefisien korelasi ketiga variabel yaitu harga diri dan konformitas terhadap kelompok dengan perilaku minum minuman beralkohol pada remaja diperoleh $R_{x 12 y}=0,125$ dengan taraf signifikansi 0,000 $(p<0,01)$. Diperoleh Fhit sebesar 21,386 dan $p=0,000(p<0,01)$ hal ini berarti hubungan ketiga variabel tersebut sangat signifikan.

Hasil perhitungan juga menunjukkan bahwa koefisien korelasi antara harga diri dengan perilaku minum minuman beralkohol pada remaja sebesar $r_{x y}=-0,313$ dengan taraf signifikansi $0,000(p \varangle 0,01)$. Hal tersebut menunjukkan bahwa makin tinggi harga diri maka akan makin rendah perilaku minum minuman beralkohol pada remaja, demikian sebaliknya. Koefisien korelasi antara konformitas terhadap kelompok dengan perilaku minum minuman beralkohol pada remaja sebesar $r_{x y}=0,397$ dengan taraf signifikansi $0,000 \quad(p \varangle 0,01)$. Hal tersebut menunjukkan bahwa makin tinggi konformitas terhadap kelompok maka makin tinggi perilaku minum minuman beralkohol pada remaja, demikian sebaliknya.

\section{Pembahasan}

Berdasarkan uji korelasi yang digunakan bahwa hipotesis mayor dan hipotesis minor yang diajukan dalam penelitian ini diterima. Hipotesis mayor diketahui bahwa ada hubungan antara harga diri dan konformitas terhadap kelompok dengan perilaku minum minuman beralkohol pada remaja. Pengujian terhadap hipotesis kedua juga diterima, yaitu ada hubungan negatif antara harga diri dengan perilaku minum minuman beralkohol pada remaja.

Pengujian terhadap hipotesis ketiga juga diterima, yaitu ada hubungan positif antara konformitas terhadap kelompok dengan perilaku minum minuman beralkohol pada remaja.

Rosen, Fox dan Gregory (1986, h.310) mengungkapkan bahwa ada beberapa individu mengkonsumsi alkohol karena ingin menghindari perasaan psikologis tertentu dan meningkatkan harga diri. Konformitas terhadap kelompok juga merupakan salah satu faktor sosial dan kultural yang menyebabkan perilaku minum alkohol. Tekanan 
yang berupa ajakan maupun paksaan membuat subyek tidak enak untuk menolak ajakan minum minuman beralkohol yang dilakukan oleh teman-teman sebayanya. Hurlock (1990, h.213) menyatakan bahwa remaja lebih banyak di luar rumah bersama dengan teman-teman sebaya sebagai kelompok, maka dapat dimengerti bahwa pengaruh teman sebaya pada sikap, minat, penampilan dan perilaku lebih besar daripada pengaruh keluarga. Bila anggota kelompok mencoba minum minuman beralkohol, maka remaja cenderung mengikutinya tanpa memperdulikan perasaan mereka sendiri.

Proses pengambilan sampel pada penelitian ini diharapkan menggunakan random sampling untuk analisa regresi tetapi karena jumlah subjek penonton konser musik yang terbatas disamping konser musik itu sendiri yang bersifat momentum juga karena peneliti beranggapan bahwa populasi yang diteliti relatif homogen maka peneliti menggunakan incindental sampling. Bila ditinjau lebih lanjut pemakaian tehnik non random sampling tidak bisa digunakan untuk analisa regresi tetapi Kerlinger dan Pedhazur ( alsa, 2001, h.19) menyebutkan salah satu asumsi yang mendasari tehnik analisa regresi adalah populasi skor variabel berdistribusi normal pada masingmasing skor variabel independen. Hadi ( alsa, 2001, h.19) menyatakan tehnik analisa regresi mendasarkan pada asumsi sebagai berikut: variabel dependen berdistribusi normal, dan sifat hubungan antara masing masing variabel independen dengan variabel dependennya adalah linear, hal inilah yang mendasari peneliti memakai analisa regresi pada penelitian ini.

Pengambilan secara non random sampling merupakan kelemahan pada penelitian ini namun Glass ( alsa, 2001, h.21) memaparkan bila sampel dalam populasi diambil tidak normal maka efek kesalahan generalisasi adalah kecil. Anderson ( alsa, 2001, h.22) pengabaian terhadap asumsi asumsi yang mendasari uji statistik tidak akan berpengaruh banyak terhadap kesimpulan penelitian. Tes statistik secara parametrik dapat diapakai dan berfungsi dengan baik meskipun asumsi asumsinya dilanggar, pelanggaran tersebut tidak akan mengganggu hasil analisis (Swediati, 2001, h.24). Pernyataan ini sesuai dengan Hadi ( 2001, h.6) yang menyatakan bahwa di labotarium statistik membuktikan tidak terpenuhinya suatu asumsi tidak terlalu besar pengaruhnya terhadap kesimpulan akhir.

\section{Simpulan dan Saran}

Kesimpulan yang dapat diambil berdasarkan hasil penelitian menunjukkan adanya hubungan yang signifikan antara harga diri dan konformitas terhadap 
kelompok dengan perilaku minum minuman beralkohol pada remaja, sehingga hipotesis pertama dalam penelitian ini diterima. Ada hubungan yang negatif dan signifikan antara harga diri dengan perilaku minum minuman beralkohol pada remaja, sehingga hipotesis kedua dalam penelitian ini diterima. Ada hubungan yang positif dan signifikan antara konformitas terhadap kelompok dengan perilaku minum minuman beralkohol pada remaja, sehingga hipotesis ketiga dalam penelitian ini diterima.

Berdasarkan hasil penelitian yang telah dilakukan, maka saran-saran yang dapat diberikan antara lain remaja diharapkan menghindari perilaku minum minuman beralkohol, remaja juga diharapkan tidak mudah terpengaruh oleh teman sebaya untuk meminum minuman beralkohol.

Bagi peneliti lain dengan penelitian sejenis disarankan menggunakan tehnik random sampling untuk analisa regresi dan meneliti faktor lain yang mempengaruhi perilaku minum minuman beralkohol, misalnya faktor perilaku dan pembelajaran, lingkungan keluarga, genetik, usia, pandangan atau keyakinan yang salah terhadap diri sendiri, agama, ego yang tidak realistik dan pendidikan.

\section{Daftar Pustaka}

Alza, Azmadi. 2001. Kontroversi uji asumsi dalam statistik parametrik. Buletin Psikologi. Yogjakarta: Fakultas Psikologi Universitas Gadjah Mada

Atkinson, RL; Atkinson, RC; Hilgard, ER. 2000. Pengantar Psikologi. Penerjemah: Nurdjanah Taufiq; Agus Dharma. Jakarta: Erlangga.

Azwar, S. 1995. Sikap M anusia : Teori dan Pengukurannya. Yogyakarta: Pustaka Pelajar. Clemes, H., Bean, R. 1995. Membangkitkan Harga Diri Anak Petunjuk Praktis Bagi Orang Tua dan Guru. Alih Bahasa: Adiwiyoto, A. Jakarta : M itra Utama.

Hadi, s. 2001. Isu uji asumsi. Buletin Psikologi. Yogjakarta: Fakultas Psikologi Universitas Gadjah Mada

Hawari, D. 1991. Penyalahgunaan Narkotik dan Zat Adiktif. Jakarta: Balai Penerbit Fakultas Kedokteran Universitas Indonesia.

http://community.qunadarma.ac.id/public/user/blogs/nameLeonardFresly92/page/ Hurlock, H. B. 1990. Psikologi Perkembangan Suatu Pendekatan Sepanjang Rentang Kehidupan. Edisi ke V. Alih bahasa : Isti Widayanti dan Soedjarwo. Jakarta : Erlangga.

. 1999. Perkembangan Anak. Jilid II. Alih bahasa : M eitasariu Tjandrasa. Jakarta : Erlangga. 
Indraningtyas, M.I.K. 2003. Perbedaan Perilaku Emotion Focused Coping Pada Remaja Berkepribadian Tipe A dan B. Skripsi (tidak diterbitkan). Semarang: Fakultas Psikologi Universitas Katolik Soegijapranata.

Kaplan, H.I., Sadock, B.J., Grebb, J.A. 1997. Sinopsis Psikiatri "Ilmu Pengetahuan Perilaku Psikiatri Klinis": Jilid I. Edisi Ketujuh. Alih Bahasa: Widjaja Kusuma. Jakarta: Binarupa Aksara.

Karamoy, S. 2004. Cegah sejak dini. Rotary International D-3400 RI Drug Abuse Commitee. Semarang: Fakultas Psikologi UNIKA (tidak diterbitkan).

Monks, F. J. 1998. Psikologi Perkembangan. Pengantar dalam Berbagai Bagian. Alih Bahasa: Siti Aditona. Yogyakarta: Gadjah M ada University Press.

M yers, D. G. 1991. Social Psychology. New York : M c. Grown Hill. Book Company. Nurcahyaningsih. 2003. Harga Diri Remaja Ditinjau Dari Dukungan Sosial Dan Jenis Kelamin. Skripsi (tidak diterbitkan). Semarang: Fakultas Psikologi Universitas Katolik Soegijapranata.

Putra, N.T.E.D. 2001. Perbedaan Harga Diri Pada Remaja Laki-laki Pengendara Sepeda M otor Antara Yang M elakukan Kebut-kebutan dan Tidak M elakukan Kebutkebutan. Skripsi (tidak diterbitkan). Semarang: Fakultas Psikologi Universitas Katolik Soegijapranata.

Rakhmat, J. 1991. Psikologi Komunikasi. Bandung : Remaja Rosdakarya.

Rohanda, 2007 dalam http://www.batukar.info/komunitas/articles/perilaku-anakjalanan-terhadap-minuman-beralkohol-di-kota-makassar-tahun-2009.

Rosen, E., Fox, R.E., Gregory, I. 1986. Abnormal Psychology. United States Of America. Santrock, J. W. 1995. Life Span Development. Jakarta : Erlangga.

Sears, D. O, Freedman, J. L ; Peplau, L. A. 1994. Psikologi Sosial. Alih bahasa : Michael Adriyanto dan Savitri Soekrisno, SH. Jakarta : Erlangga.

Siregar, I.M.P. 2002. Beberapa Aspek Penggunaan Zat Psikoaktif. Jurnal Psikologi. Bandung: Fakultas Psikologi Universitas Padjajaran, v.5, no.1 (h.18-31).

Swediati, N. 2001. Perlukah uji asumsi statistik dilalukan?. Buletin Psikologi. Yogjakarta: Fakultas Psikologi Universitas Gadjah Mada

Yanny, D. 2001. Narkoba : Pencegahan dan Penanganannya. Jakarta: PT. Elexmedia Komputindo.

Zebua, A. S. \& NurNurdjayadi, R. D. 2001. Hubungan antara konformitas dan konsep diri dengan perilaku konsumtif pada remaja putri. Jurnal Phronesis. Vol 3. Nomor 6. bulan Desember. 